University of Nebraska - Lincoln

DigitalCommons@University of Nebraska - Lincoln

Faculty Publications, UNL Libraries

Libraries at University of Nebraska-Lincoln

December 2007

\title{
Library Organization Information Literacy Units
}

Virginia A. Baldwin

University of Nebraska-Lincoln, vbaldwin2@unl.edu

Follow this and additional works at: https://digitalcommons.unl.edu/libraryscience

Part of the Library and Information Science Commons

Baldwin, Virginia A., "Library Organization Information Literacy Units" (2007). Faculty Publications, UNL Libraries. 130.

https://digitalcommons.unl.edu/libraryscience/130

This Article is brought to you for free and open access by the Libraries at University of Nebraska-Lincoln at DigitalCommons@University of Nebraska - Lincoln. It has been accepted for inclusion in Faculty Publications, UNL Libraries by an authorized administrator of DigitalCommons@University of Nebraska - Lincoln. 
Baldwin, Virginia A., "Library Organization Information Literacy Units "

Published in "Information Literacy Column," Science \& Technology Libraries27(4)

(2007) Haworth Press, Inc.

\begin{abstract}
Information Literacy is an important component of library and information organizations at the local, regional, national and international level. From the newly formed Science and Technology Section's (STS) Information Literacy Committee to the long standing Instruction Section (IS), both of which are within the Association of College and Research Libraries (ACRL) Division of the American Library Association (ALA), the level of functionality varies. This column reviews information literacy/library instruction units in national and international organizations and their various attributes.
\end{abstract}

\title{
Library Organization Information Literacy Units
}

Information Literacy is an important component of library and information organizations at the local, regional, national and international level. From the newly formed Science and Technology Section's (STS) Information Literacy Committee to the long standing Instruction Section (IS), both of which are within the Association of College and Research Libraries (ACRL) Division of the American Library Association (ALA), the level of functionality varies. This column reviews information literacy/library instruction units in national and international organizations and their various attributes.

\section{SCIENCE AND TECHNOLOGY RELATED}

Science and technology information literacy is the primary interest of four committees and one interest group in two library organizations and two divisions of science and engineering organizations. The organizations are the American Library Association and the Special Libraries Association and the divisions are a part of the American Chemical Society and the American Society for Engineering Education. While information literacy may appear to be only tangentially related to non-academic libraries, the level of information literacy that a scientist or engineer has obtained upon entering the profession can affect the level of service required from the nonacademic librarian. Added to this, these librarians find it valuable to conduct group or individual training sessions for their patrons. The library association that has a significant nonacademic membership is the Special Libraries Association (SLA) and this association has several science and technology related divisions. Two divisions of SLA have which have components that relate to instruction are the Chemistry Division and the Information Technology Division. The latter is not specifically science and technology related and will be discussed under the international section. 


\section{SLA Chemistry Division Ad-Hoc Committee for Information Literacy}

From Co-Chair Cory Craig “The SLA Chemistry Division Ad-Hoc Committee for Information Literacy was created at the 2004 SLA Annual meeting. The committee's goal is to contribute to information literacy in the field of chemistry. We chose to do this by developing a list of information competencies for chemistry undergraduates using a subject-specific approach to information literacy. Our approach has been to identify both a specific set of skills, and the chemistry resources which should be mastered in order to demonstrate information literacy within the field of chemistry, rather than providing a broad framework with very general outcomes, as some recent standards have done.”

\section{ALA/ACRL/STS Information Literacy Committee}

This is a newly formed committee that will hold its first meeting at ALA Midwinter 2007. It is a natural follow on to the ACRL board approved "Information Literacy Standards for Science and Engineering/Technology that were developed by an STS Task Force and are available at http://www.ala.org/ala/acrl/acrlstandards/infolitscitech.htm. The committee charge as it appears on the STS Web site at http://www.ala.org/ala/acrl/aboutacrl/acrlsections/sciencetech/stscommittees/stscommittees.htm is: "To provide, evaluate and/or develop resources for advancing information literacy in science and engineering (e.g. models for assessing student performance, teaching methods, instructional design, and tips for working with faculty on instruction-related issues); to serve as a liaison to other instruction-oriented groups as appropriate (e.g. IS, ILAC, etc.) The committee chair serves as liaison to the ACRL Information Literacy Advisory Committee and is a member of the STS Council.” The committee does not yet have its own Web site.

\section{American Chemical Society Division of Chemical Information (CINF), Education Committee}

The CINF Division Web site, http://www.acscinf.org/, links to the Education Committee which states: "The primary objective of the committee is to provide educational outreach to chemical information users, of all degrees of experience, in all venues. To this aim we are continuously developing and sponsoring resources for chemical information instruction and training, including:

- Teaching Chemical Information: Tips and Techniques Workshop Offered at national and regional ACS meetings

- Clearinghouse for Chemical Information Instruction Materials co-sponsored with the SLA Chemistry Division.

- Participating regularly in the CINF technical programs to explore and discuss current chemical information education issues."

Teaching tips and techniques from past workshops are available at:

http://www-sul.stanford.edu/depts/swain/hosted/cinf/index.html. The Web site CLEARINGHOUSE FOR CHEMICAL INFORMATION INSTRUCTIONAL MATERIALS (CCIIM) links to the Indiana University Web site 
http://www.indiana.edu/ cheminfo/cciimnro.html that is co-sponsored by the ACS/CINF and the SLA Chemistry Division. A remarkable example of interorganizational cooperation, this Web site has a wealth of valuable chemical information instructional material made freely available online.

Contributions from the Education Committee are made to the CINF Division Listserv, linked from http://www.acscinf.org/ and the CINF Division Newsletter, linked from http://www.acscinf.org/.

\section{American Society for Engineering Education (ASEE) Engineering Libraries Division (ELD)}

Information Literacy Special Interest Group (SIG). From the Website: http://eld.lib.ucdavis.edu/sigs/sigs.php ELD SIGs "are charged to facilitate the exchange of ideas among scholars on a specific topic of common interest, mainly via e-mail forums. They can also, if interested, coordinate special conference programming under the direction of the Program Chair. Any additional activities, such as sponsoring an event or producing official publications must be approved by EC [Executive Committee]. SIG listservs are open to members and non-members alike" and "The Information Literacy SIG "Focuses on issues related to information literacy and library instruction within engineering libraries or engineering disciplines.” In keeping with that charge, the Information Literacy SIG promotes the use of the open ELD listserv, ELDNET-L for the discussion of information literacy issues.

Accreditation and Standards Committee. Formed to address the Accreditation Board for Engineering and Technology (ABET) accreditation standards for Engineering Programs, the focus has been on those criteria that relate to information literacy standards and library instruction. Featured at the ASEE conference in June of 2007 is a morninglong workshop “Assessment and Life Long Learning”. Based on engineering faculty and librarian collaboration, the emphasis of the workshop is on methods to achieve the ABET criterion that deals with lifelong learning by teaching students in engineering courses how to effectively use information.

\section{NATIONAL ORGANIZATIONS}

The Association of College and Research Libraries Division of the American Library Association has three separate units that were formed for distinct information literacy related missions. One exists as a separate section, one is an advisory committee, and the third is an institute that overseas information literacy immersions.

\section{ALA/ACRL Instruction Section (IS)}

The Instruction Section strategic plan is modeled after the ACRL strategic plan: http://www.ala.org/ala/acrlbucket/is/organizationacrl/handbookacrl/strategicplan.htm. 
The IS Newsletter is freely available at:

http://www.ala.org/ala/acrlbucket/is/publicationsacrl/newslettersacrl/newsletters.htm.

Links to IS Publications and Bibliographies can be accessed at:

http://www.ala.org/ala/acrlbucket/is/publicationsacrl/publications.htm. These include a variety of bibliographies, guidelines, links to past IS newsletters and other publications, most of which are freely available online.

Information about the IS ILI-L (the Information Literacy Instruction Discussion List) can be found at http://www.ala.org/ala/acrlbucket/is/ilil.htm.

The Instruction Section has a complete committee structure. A link from the IS Web site, http://www.ala.org/ala/acrlbucket/is/iscommittees/commiteecharges.htm. lists the IS committees, their charges, and their Web sites. The following are several of the most pertinent committees:

- Information Literacy Best Practices Committee. Charge: “To promote best practices in information literacy and library instruction by developing, maintaining, and promoting the 'Characteristics of Programs of Information Literacy that Illustrate Best Practices: A Guideline’ and related web site.”

Information Literacy Best Practices Committee Web site: http://www.ala.org/ala/acrlbucket/is/iscommittees/webpages/bestpracticesa/index.htm.

- Information Literacy in the Disciplines Committee. Charge: "To gather and promote information literacy standards and curricula developed by accrediting agencies, professional associations, and institutions of higher education nationally and internationally. The Committee presents its data on Section-sanctioned web sites, including 'Information Literacy in the Disciplines' and 'Information Literacy Around the Globe.' The Committee shall review and update the content annually."

Information Literacy in the Disciplines Committee Web Site: http://www.ala.org/ala/acrlbucket/is/iscommittees/webpages/ild/index.htm.

Information Literacy in the Disciplines Web site: http://www.ala.org/ala/acrlbucket/is/projectsacrl/infolitdisciplines/index.htm.

- Instructional Technologies Committee. Charge: “To educate and inform membership about the impact of technology on instruction by posting 'InfoTech Tips and Trends' topics on the IS web site and announcing the profiles on ILI-L. The committee is responsible for annually updating the 'Classroom Control Systems' on the Section web site, including verifying existing listings and researching new systems. The committee is also responsible for updating the 'Tips for Developing Effective Web-Based Instruction."” 
Instructional Technologies Committee Web Site:

http://www.ala.org/ala/acrlbucket/is/iscommittees/webpages/instructionaltechnologies/index.htm

InfoTech Tips and Trends Web site:

http://www.ala.org/ala/acrlbucket/is/iscommittees/webpages/emergingtech/techtips/index.htm

Tips for Developing Effective Web-Based Library Instruction Web site:

http://www.ala.org/ala/acrlbucket/is/iscommittees/webpages/teachingmethods/tips.htm

\section{ACRL Information Literacy Advisory Committee (ILAC)}

From http://www.ala.org/ala/acrl/aboutacrl/acrlcomm/infolitadvisory.htm the ILAC Charge: "To monitor developments in the field of information literacy and work with interested parties to develop appropriate activities within the Institute for Information Literacy, Instruction Section, AASL/ACRL Interdivisional Committee on Information Literacy, and ACRL Board of Directors.”

The ILAC coordinated with ACRL units and information literacy standards developers to produce the guide: Tip Sheet for Developing Subject-Specific Information Literacy Standards, available online at: http://www.ala.org/ala/acrl/aboutacrl/acrlcomm/TipSheetSubj-SpecILStandards.pdf

\section{ACRL's Institute for Information Literacy (IIL)}

The IIL Web site

http://www.ala.org/ala/acrl/acrlissues/acrlinfolit/professactivity/iil/welcome.htm Links to the IIL Organization Web site, http://www.ala.org/ala/acrl/acrlissues/acrlinfolit/professactivity/iil/iilorganization/organization.htm where the IIL mission and goals are described.

"Mission: The Institute for Information Literacy (I.I.L.) is dedicated to playing a leadership role in assisting individuals and institutions in integrating information literacy throughout the full spectrum of the educational process.

“Goals

- Prepare librarians to become effective teachers of information literacy programs

- Support librarians and other educators and administrators in playing leadership roles in the development and implementation of information literacy programs

- Forge new relationships throughout the educational community to work towards information literacy curriculum development

- Offer opportunities for growth and development in the changing field of information literacy."

The IIL's national immersion program of intensive four and one half day work on all aspects of information literacy is described at http://www.ala.org/ala/acrl/acrlissues/acrlinfolit/professactivity/iil/immersion/immersionprograms.htm. Details about upcoming immersion programs are also available at this site. 
Another American organization, a Canadian Organization, and two from "down under” are profiled below.

\section{American Society for Information Science and Technology (ASIST) Special Interest Group (SIG): Information Needs, Seeking and Use (USE)}

The ASIST Special Interest Group USE deals with aspects of the user of information, an important consideration in information literacy instruction.

ASIST SIG/USE Web site: http://iats-coe1.missouri.edu/ siguse/index.php.

From the link “About USE”, http://iatscoe1.missouri.edu/ siguse/about.html: "SIG/USE members are concerned with people's behavioral and cognitive activities as well as their affective states as they interact with information. These activities include:

- creating information needs

- recognizing information needs

- seeking (and not seeking) information that will address those needs

- exploring information sources present in one's context/situation

- retrieving information from available information sources

- sharing information with others

- managing personal information collections

- communicating and collaborating with others concerning an information need or information resources using information and other interactions between people and information.

"The SIG wishes to promote contextual studies of human information-related behavior and provision of information services, and to encourage the application of the study results to information systems design.”

The "SIG USE 2002 Bibliography of resources is available at: http://iatscoe1.missouri.edu/ siguse/Bibliography_2002.html. These resources are a wide-ranging variety of publications by SIG USE members.

SIG USE has an E-mail Discussion List, siguse-l. Information about the list and subscribing to it is available at: http://mail.asis.org/mailman/listinfo/siguse-l.

\section{Australia and New Zealand Institute for Information Literacy (ANZIL)}

From the ANZIL Web site, http://www.anziil.org/ , "The Australian and New Zealand Institute for Information Literacy (ANZIIL) supports organisations, institutions and individuals in the promotion of information literacy and, in particular, the embedding of information literacy within the total educational process. 
“The Institute identifies, facilitates, fosters and supports best practice in information literacy through

- Professional Development

- Promotion, Marketing and Advocacy

- Research

“Activities and initiatives primarily target vocational and higher education. The Institute works in collaboration with a range of national and international organisations, forums and groups to complement the existing information literacy aims, objectives and initiatives of ANZIIL.

“ANZIIL also works closely with the Council of Australian University Librarians (CAUL), Council of New Zealand University Librarians (CONZUL), Australian Library and Information Association (ALIA), NWGTLS (National Working Group for TAFE Library Services) and Library and Information Association of New Zealand Aotearoa (LIANZA).”

\section{Australian Library and Information Association (ALIA) Information Literacy Forum}

The ALIA Information Literacy Forum http://www.alia.org.au/groups/infolit/ "fosters a common understanding of and advocates for information literacy within ALIA and the general community.

"The Forum promotes professional development opportunities in information literacy for library and information services personnel.

"This year it will continue to promote the library's role in developing information literacy, continuing involvement with the National Information Literacy Coalition, strategy planning for integration of information literacy into various sectors, and participation in relevant conferences. Communication includes a quarterly newsletter and the annual online forum. The planning committee [sic] meet bi-monthly via teleconference.”

\section{Canadian Library Association Information Literacy Interest Group}

The Canadian Library Association (http://www.cla.ca/) does have an Association of College and University Libraries Division. However, information literacy is addressed as an interest group in the parent association, the Information Literacy Interest Group. The group's stated “Terms of Reference” is http://cybrary.uwinnipeg.ca/ilig/About_Us.htm :

- “To promote information literacy programming as an essential library service.

- To provide a forum for the discussion of activities, programs and problems in the area of information literacy. 
- To contribute to the education and training of librarians and others for providing information literacy programming.

- To serve as a channel of communication on information literacy."

The group sponsors the Information Literacy in Canada blog at: http://blog.uwinnipeg.ca/ilig/

Their Web site is at: http://cybrary.uwinnipeg.ca/ilig/ and states "This site aims to provide a forum for the exchange of ideas and resources supporting information literacy programming in Canadian libraries. We hope you will consider contributing! Share your thoughts on a current issue, report on a recently attended workshop, highlight current developments in your library...”

\section{INTERNATIONAL}

Profiled below are one organization, a forum with a broad membership of national, international, and corporate organizations, and sections of two other organizations all of which are international in scope.

\section{Sections of the SLA/IT Division that have instruction components}

As stated by the association profile, "The Special Libraries Association (SLA) was founded in 1909 in the state of New York and is now the international association representing the interests of thousands of information professionals in over eighty countries worldwide." (http://www.sla.org/content/SLA/AssnProfile/index.cfm). In its vision statement, linked from this Web site, SLA "is the global organization for innovative information professionals and their strategic partners.”

The IT Division has a blog: http://units.sla.org/division/dite/itblogfeed.html, and a listserv, SLA-DITE@lists.sla.org. Subscription instructions are linked from the SLA Division Lists Web site at http://www.sla.org/content/community/lists/divisionlists5979.cfm.

The following two sections of IT are of interest from an information literacy perspective since they deal with emerging technologies for delivery and with matters of use and evaluation of information quality. The descriptions below are taken from the SLA Divisions Web site links from http://www.sla.org/content/community/units/divs/division.cfm.

\section{IT Division Blogging Section}

Web Address: http://units.sla.org/division/dite/blogging_new.html

Blog address http://sla-divisions.typepad.com/itbloggingsection/

Description: "The Blogging Section was created in June 2005 at the Annual Conference in Toronto. The official scope of the Blogging Section is: Provides a forum for members to exchange information on the technologies and applications of blogs and RSS. Central 
to this section is the development of blogs by and for information professionals and their customers, including design, development, structure, delivery, and promotion. This section monitors and reports on emerging new technologies and offers education and training on their effective use, implementation and management.”

\section{Digital Content Section of DITE}

Web Address: http://units.sla.org/division/dite/digital_new.html.

Description: “The Digital Content Section (formerly the Online Section) of ITE provides a forum for members to address the needs of users and providers of all kinds of computerized information. Central to this section is digital content, including its access, use, management, navigation, selection, implementation, training, dissemination, evaluation, and manipulation. Selection concerns include contract negotiations, integration with the rest of the collection, instruction \& documentation, and dissemination/access method whether via modem, network, Intranet or Internet, or installation standalone. Manipulation includes data extraction and visualization, search and retrieval, data mining, archiving, and warehousing. Critical to this section is a focus on the evaluation of the quality of information.”

\section{National Forum on Information Literacy}

From a statement on their "Members" Web site, http://www.infolit.org/members.html, the "Forum is a broadly-based group of over 90 national (and more recently international and corporate) organizations that are committed to individual empowerment within the information society." It was created in 1989 as a response to the recommendations of the American Library Association's Presidential Committee on Information Literacy.

Their Web site is: http://www.infolit.org/. The Information Literacy Weblog is linked from this site: http://information-literacy.blogspot.com/, with regular entries and an archive back to 2005. Also linked under "Resources" is a Publications Web site at http://www.infolit.org/resources.html with a listing of a wide range of resources that are relevant to information literacy and could well be worthy of a visit.

\section{Library Orientation Exchange (LOEX) Clearinghouse for Library Instruction}

The link, "About LOEX”, from the LOEX Web site, http://www.emich.edu/public/loex/, states: "LOEX is a self-supporting, non-profit educational clearinghouse for library instruction and information literacy information. Founded in 1971 after the 'First Annual Conference on Library Orientation' at Eastern Michigan University, LOEX (Library Orientation Exchange) has grown from a lending repository of library instruction materials and host of an annual conference on the subject to an internationally known organization that serves as a conduit for those working in the field. We provide information on all aspects of instruction and information literacy to libraries and librarians who are institutional members. Our collections, which have recently become an historical archive of library instruction materials, include both print and non- 
print resources donated by member libraries and librarians. LOEX members may still borrow these materials or copies can be made and sent.

"In addition to the LOEX collection, the clearinghouse still hosts an annual conference with published proceedings, produces a quarterly publication featuring articles by teaching librarians and a monthly current awareness e-letter, plus this Web site which points to examples of work in the field of library instruction and information literacy.

"In 2006, LOEX has over 650 member libraries in the United States, Canada, the Caribbean, Europe, Australia, and New Zealand.”

LOEX Publications include a quarterly, LOEX Quarterly, and the monthly current awareness service, LOEX Currents. An electronic version of LOEX Quarterly is available to individuals at member libraries by request. LOEX Quarterly includes practical articles on library instruction and information literacy as well as reports on instruction and information literacy initiatives around the world. LOEX Currents is distributed to affiliates of member libraries through the LOEX E-list.

The LOEX Web site, Instruction Resources, at http://www.emich.edu/public/loex/resources.html has four "Teaching and Resources Links”, each of which is a set of links to resources. The four are: Tutorials, Tours, Evaluating Web Sources, and Teaching Resources. The "Current Information" section has links to many discussion lists, four Web logs, online magazines, journals and other publications, numerous organizations and programs, and links to Web sites featured in their quarterly publication, all related to information literacy.

\section{International Federation of Library Associations and Institutions (IFLA) Information Literacy Section (ILS)}

From the ILS Web site, http://www.ifla.org/VII/s42/index.htm, "This new section existed previously as the User Education Roundtable but due to increasing interest in information literacy activities worldwide the Roundtable became the Information Literacy Section in 2002. The primary purpose of the Information Literacy Section is to foster international cooperation in the development of information skills education in all types of libraries. The Section focuses on all aspects of information literacy including user education, learning styles, the use of computers and media in teaching and learning, networked resources, partnerships with teaching faculty in the development of instructional programmes, distance education, and the training of librarians in teaching information and technical sills. It is the mission of the Section to disseminate information on information literacy programmes and trends. The Section is very willing to work closely with other IFLA bodies and other organizations in the development of programmes, workshops and projects related to information skills instruction.”

From the IFLA ILS 2006-2007 strategic plan web site, http://www.ifla.org/VII/s42/annual/sp42.htm , the stated mission of the section is "The primary purpose of the Information Literacy Section is to foster international cooperation 
and to promote information literacy in all types of libraries, as well as to lead the information world in promoting information literacies as they relate to the three IFLA Pillars: Society, Membership and the Profession.” Three goals are stated. They encompass promoting (the importance of information literacy for all sectors of society), monitoring, and communicating (best practice with respect to information literacy), and providing opportunities (for knowledge, skills and abilities).

The IFLA ILS Web site links to several publications, one of which is the 60 page online publication, Guidelines on Information Literacy for Lifelong Learning, by Jesus Lau, Boca Del Rio, Veracruz, Mexico. Several chapters of this publication are worthy of perusal for the sci-tech librarian as lifelong learning is a particularly important pursuit for the science and engineering professionals. The Web site also links to issues of its online Newsletter and its annual reports, among other information.

Information about the IFLA Information Literacy Section Discussion List, InfoLit$L$ is available at http://infoserv.inist.fr/wwsympa.fcgi/info/infolit-l. Issues of the Information Literacy Section Newsletter are linked from the main ILS Web site.

The IFLA ILS International Information Literacy Resources Directory is available at http://www.uv.mx/usbi\%5Fver/unesco/. Created on behalf of UNESCO to record information literacy materials from different parts of the world, the Web site for this directory has statements regarding the general objectives, justification, background, and methodology. To quote the Justification link, "The information literacy initiative of UNESCO/IFLA requires an assessment of what has been achieved in leading countries, and explore [sic] what direction should be taken to foster further development in libraries, and nations that need to start a program in this field. There are information literacy outcomes that could be used as a model/guide for new information literacy actions in different parts of the world. A directory of internationally relevant tools can benefit the international community because some of these tools could be used as they are, can be adapted or can serve as examples to build new information literacy applications.”

\section{CONCLUDING REMARKS}

Formed to promote information literacy in a variety of ways, these organizations and units offer online resources, blogs, newsletters, and discussion lists that serve to assist our information literacy programs and library instruction. Most of these valuable resources are freely available to nonmembers. By joining and contributing to an appropriate organization, the sci-tech librarian can find accessible the latest studies, tips, teaching methods and other resources and will assure progressively effective library instruction. 